\title{
Monolithic PM Raman fiber laser at 1679 nm for Raman amplification at $1810 \mathrm{~nm}$
}

Svane, Ask Sebastian; Rottwitt, Karsten

Published in:

CLEO/Europe 2013 - European Conference on Lasers and Electro-Optics

Publication date:

2013

Link back to DTU Orbit

Citation (APA):

Svane, A. S., \& Rottwitt, K. (2013). Monolithic PM Raman fiber laser at $1679 \mathrm{~nm}$ for Raman amplification at 1810 nm. In CLEO/Europe 2013 - European Conference on Lasers and Electro-Optics IEEE.

\section{General rights}

Copyright and moral rights for the publications made accessible in the public portal are retained by the authors and/or other copyright owners and it is a condition of accessing publications that users recognise and abide by the legal requirements associated with these rights.

- Users may download and print one copy of any publication from the public portal for the purpose of private study or research.

- You may not further distribute the material or use it for any profit-making activity or commercial gain

- You may freely distribute the URL identifying the publication in the public portal

If you believe that this document breaches copyright please contact us providing details, and we will remove access to the work immediately and investigate your claim. 


\title{
Monolithic PM Raman fiber laser at $1679 \mathrm{~nm}$ for Raman amplification at $1810 \mathrm{~nm}$
}

\author{
Ask Sebastian Svane \& Karsten Rottwitt \\ DTU Fotonik, Department of Photonics Engineering. Technical University of Denmark, Ørsteds Plads 343, DK-2800 Kgs. Lyngby, \\ Denmark
}

Stimulated Raman scattering (SRS) has been subject to much attention within the field of fiber lasers and amplifiers as it provides an extended wavelength coverage in comparison to rare-earth based devices. Motivated by the projected capacity crunch [1], different approaches are being explored to increase the capacity of communication systems [2]. One approach is by exploiting new optical wavelength bands, outside the conventional amplification windows. In the development of lasers and amplifiers in the short wave IR above the Erbium band, SRS seems to be a promising candidate. In this paper we demonstrate a monolithic RM Raman fiber laser (RFL), which acts as a pump for a Raman amplifier (RA) at $1810 \mathrm{~nm}$. The lasing wavelength of a RFL, thus also for a RA, can in principle be designed arbitrarily within the entire wavelength range from the Erbium band up to the Thulium/Holmium band by the utilization of cascaded SRS [3].

(a)

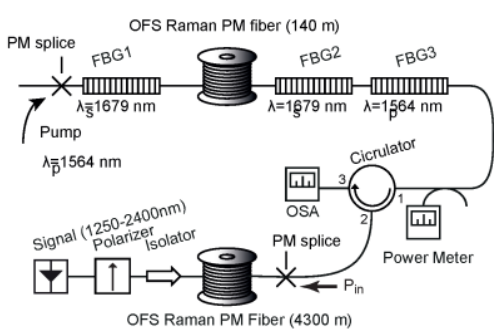

(b)

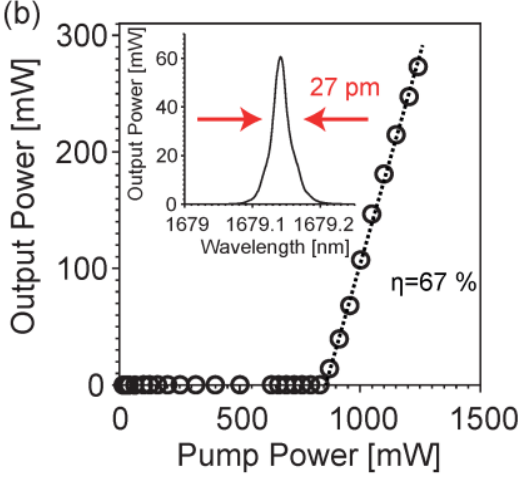

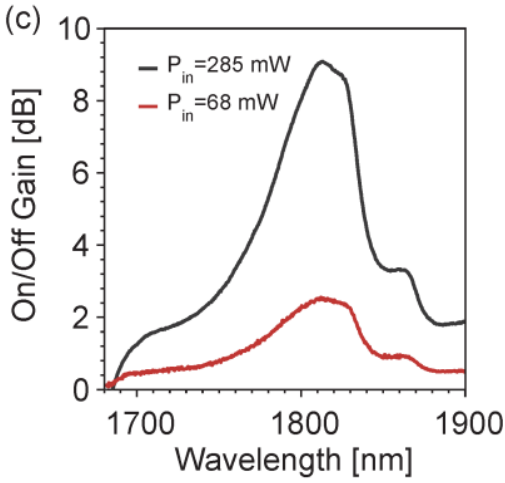

Fig. 1 (a) Experimental setup of the RFL and RA (b) Laser curve for the RFL (c) Measured on/off gain of the RA

The Experimental setup is shown in Fig. 1a, and consists of a RFL pumped at $1564 \mathrm{~nm}$ lasing at the first stokes shift at $1679 \mathrm{~nm}$ [4] along with a RA with a gain maximum at the second stokes shift at $1810 \mathrm{~nm}$. The monolithic RLF cavity contains two signal fiber Bragg gratings (FBGs) 1 and 2 which define the laser cavity, along with a pump grating, FBG3, that enable two pass amplification. The gratings are written directly in the fiber, with a $50 \mathrm{~mm}$ phase mask, to avoid additional splice losses in the cavity. To address the issue of intensity noise transfer from the RFL to the RA, the cavity FBGs were temperature stabilized to reduce the RFL output intensity fluctuations. The RA is based on $4.3 \mathrm{~km}$ PM fiber where the pump is launched through a circulator in reverse with respect to the launched signal stemming from a NKT SuperK source. Both devices are based on a segment of OFS PM Raman fiber, with an estimated propagation loss of 0.42/0.46/1.3 dB/km at 1564/1679/1810 $\mathrm{nm}$. The Raman gain coefficient was measured to be $\mathrm{g}_{\mathrm{R}}=2.66 / 2.35 \mathrm{~W}^{-1} \mathrm{~km}^{-1}$ at $1679 / 1810 \mathrm{~nm}$.

The laser curve of the RFL is depicted in Fig. 1b, with a slope efficiency of $67 \%$. The high slope efficiency was obtained by optimizing the Q-factor of the cavity compared to the fiber length, through the reflectivity of the inscribed FBGs. A linewidth (LW) of $27 \mathrm{pm}(2.9 \mathrm{GHz})$ is obtained at an output power of $275 \mathrm{~mW}$. The LW was sufficiently wide to avoid stimulated Brillouin scattering in the RA. The measured Raman gain is plotted in Fig. $1 \mathrm{c}$, which peaks at $1810 \mathrm{~nm}$ with an on/off gain of $9 \mathrm{~dB}$ for an input power of Pin=285 $\mathrm{mW}$ at $1679 \mathrm{~nm}$. Based on the fiber parameters, signal transparency for up to $15 \mathrm{~km}$ should be attainable at current power levels, whereas discrete gain of $18 \mathrm{~dB}$ should be achieved for $500 \mathrm{~mW}$. In comparison for a typical SMF no net gain would be possible for pump powers below $1 \mathrm{~W}$, assuming similar losses and $\mathrm{g}_{\mathrm{R}}=0.3 \mathrm{~W}^{-1} \mathrm{~km}^{-1}$.

In conclusion, we have demonstrated a Monolithic PM RFL operating above the Erbium band at $1679 \mathrm{~nm}$, which was shown to be a viable pump laser for a RA centred at $1810 \mathrm{~nm}$. Based on our findings, we show that in spite of high transmission losses at $1810 \mathrm{~nm}$, a high Raman gain coefficient provided by the OFS PM Raman fiber in conjunction with our developed RFL, has the potential to provide a high discrete gain but also distributed amplification across tens of kilometers at reasonable pump powers levels.

\section{References}

[1] D. J. Richardson, "Filling the Light Pipe", Science, Vol. 330, 6002 (2010).

[2] P. J. Winzer, "Modulation and multiplexing in optical communication systems", IEEE Leos Newsletter (2009)

[3] S. G. Grubb, T. Strasser, W. Y. Cheung, W. A. Reed, V. Mizrahi, T. Erdogan, P. J. Lemaire, A. M. Vengsarkar, and D. J. DiGiovanni, "High-power 1.48 mm cascaded Raman laser in germanosilicate fibers", Procc. of Opt. Amp. and Appl,Davos, Switzerland, 197 (1995). 